

ISSN : 2581-1320 (Print) ISSN : 2581-2572 (Online)

Homepage: http://ejurnal.ikippgribojonegoro.ac.id/index.php/J-ABDIPAMAS

\title{
IbM BAGI GURU SMP N 34 SEMARANG DALAM MENYUSUN SOAL BERSTANDAR UN
}

\author{
AB. Prabowo, KA. ${ }^{1}$, Suwandi $^{2}$, Bambang Sulanjari ${ }^{3}$, Sukma Nur Ardini ${ }^{4}$ \\ ${ }^{1}$ Universitas PGRI Semarang. Email: bowo2609@yahoo.com \\ ${ }^{2}$ Universitas PGRI Semarang. Email: dr_suwandi2@yahoo.com \\ ${ }^{3}$ Universitas PGRI Semarang. Email: bbgsljr@gmail.com \\ ${ }^{4}$ Universitas PGRI Semarang. Email: sukmanurardini27@gmail.com
}

\begin{abstract}
The purpose achieved in this community service is teachers of SMPN 34 Semarang are able to compile the question items using UN standardized. Partner's problem in this activity is that SMPN 34 is considered a new school which is using Curriculum 2013. In addition, their knowledge is still not adequate in preparing the question items, especially UN standardized. Even tough when it refers to their potential, they have high potential availability. Lecture methods, group discussions and training were used with key informant Dr. Dwi Anggani LinggarBharati, M.Pd and supported by prof. Dr. Suwandi, M.Pd. The first material gives participants knowledge of how the rules of standard question items are developed. The second material gives the knowledge how to form questions based on Bloom's Taxonomy. The third material gives strategies how to prepare learners to deal with UN. The final material is an essential material about the UN. Material presented by the key informant is the novelty value for this service. Therefore, the participants were very enthusiastic about the practice of composing question items based on standardized UN as the target of this event.
\end{abstract}

Keywords: UN question items, Teacher of SMP 34 Semarang

\begin{abstract}
ABSTRAK
Tujuan yang hendak dicapai dalam pengabdian masyarakat ini adalah para guru SMPN 34 Semarang mampu menyusun soal berstandar UN. Permasalahan mitra dalam kegiatan ini adalah SMPN 34 merupakan sekolah yang masih baru dalam menggunakan Kurikulum 2013. Selain itu, pengetahuan mereka masih sangat minim dalam menyusun soal terutama berstandar UN padahal potensi yang mereka miliki sangat tinggi. Metode ceramah, diskusi kelompok dan pelatihan digunakan dalam pengabdian ini dengan narasumber utama Dr. Dwi Anggani LinggarBharati, M.Pd dan disupport oleh Prof. Dr. Suwandi, M.Pd. Materi pertama memberikan peserta pengetahuan mengenai bagaimana kaidah pengembangan soal terstandar. Materi kedua memberikan pengetahuan bagaimana bentuk pertanyaan berdasarkan Taxonomy Bloom. Materi ketiga memberikan strategi bagaimana menyiapkan peserta didik untuk menghadapi UN. Materi terakhir adalah tentang materi esensial UN. Materi yang disampaikan oleh narasumber merupakan nilai kebaruan (novelty) bagi pengabdian ini. Oleh karena itu, peserta sangat antusias berlatih menyusun soal berstandar UN sebagai luaran pengabdian ini.
\end{abstract}

Kata kunci : Soal berstandar UN, Guru SMP, 


\section{PENDAHULUAN}

Pentingkah bagi guru untuk mampu membuat soal? Apabila guru dihadapkan pada pertanyaan ini, dapat dipastikan jawaban yang muncul adalah 'sangat penting'. Soal mempunyai peran yang sangat penting dalam proses belajar mengajar karena soal memiliki fungsi sebagai alat atau perangkat yang digunakan oleh guru untuk mengukur sejauh mana pemahaman siswa terhadap jalannya pembelajaran. Dari sisi siswa, soal pun dapat digunakan sebagai alat untuk mengukur sejauh mana kemampuan mereka dalam memahami pelajaran yang selama ini mereka terima. Soal adalah apa yang menuntut jawaban dan sebagainya (pertanyaan dalam hitungan dan sebagainya), hal yang harus dipecahkan, atau masalah (KBBI). Seorang guru sangat perlu memiliki kemampuan membuat soal yang baik, karena soal merupakan alat evaluasi yang dipergunakan untuk mengukur kemampuan siswa dalam menguasai suatu kompetensi dalam pembelajaran. Tanpa kemampuan tersebut, dapat dikatakan bahwa seseorang gagal menjadi seorang guru yang berkualitas.

Sampai saat ini masih ditemukan fakta mengenai ketidakmampuan guru dalam membuat soal yang baik yang sesuai dengan kebutuhan. Masih banyak guru membuat soal yang kurang baik. Soal dikatakan kurang baik diantaranya yaitu soal yang menggunakan tata bahasa yang kurang jelas, pilihan jawaban yang panjangnya tidak sama, soal yang seringkali berhubungan pada jawaban soal sebelumnya, dan pilihan jawaban yang berupa angka yang ditulis secara acak atau tidak berurutan. Menurunnya kualitas penyerapan materi siswa juga dirasa karena pembuatan soal yang tidak direvisi dan kurang bervariasi dari tahun ke tahun.Guru perlu menyadari bahwa sebelum membuat soal alangkah baiknya jika mengetahui terlebih dahulu bagaimana alur pembuatan soal yang baik.

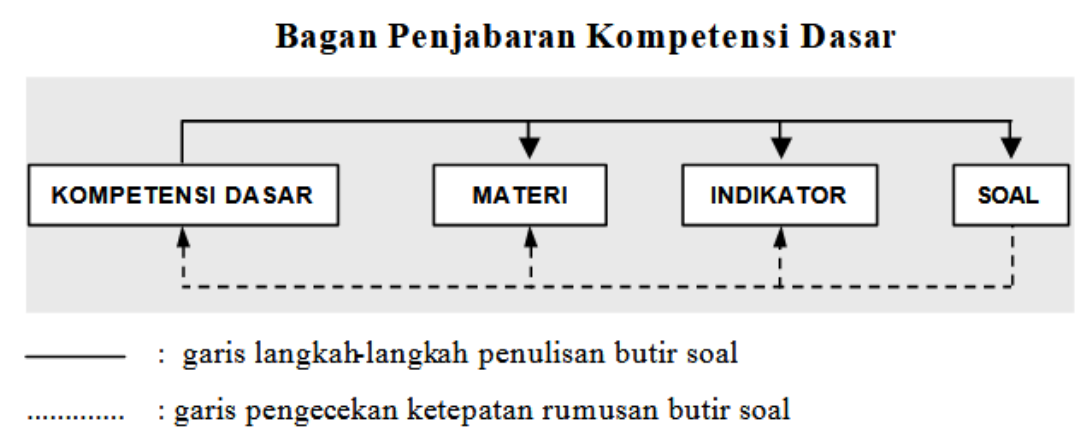

(Sumber: Pusat Penilaian Pendidikan Balitbang-Depdiknas:2007)

Dari alur di atas, guru dapat menggunakan Standar Kompetensi Lulusan (SKL) siswa sebagai landasan utama dan melihat materi dan Standar Kompetensi serta Kompetensi Dasar yang akhirnya menjadikan beberapa indikator soal dan butir soal.

Menurut Arikunto Suharsimi (2003), soal yang baik harus mempunyai syaratsyarat sebagai berikut: 1) Harus efisien (Parsimony), 2) Harus baku (Standardize), 3) Mempunyai norma, 4) Objektif, 5) Sahih (Valid), 6) Andal (Reliabel). Oleh sebab itu, untuk memperoleh soal yang baik, soal tersebut harus di ujicobakan terlebih dahulu dan 
hasilnya dianalisis sehingga memenuhi syarat-syarat tersebut di atas. Oleh karena itu, pengabdian masyarakat ini bertujuan untuk memberikan pengetahuan bagaimana menyusun sebuah soal yang sesuai dengan kaidah penyusunan soal terutama bagi guru SMPN 34 Semarang. Narasumber utama yaitu Dr. Dwi Anggani LB, M.Pd merupakan bagian dari tim narasumber pusat (Kemendikbud). Oleh karena itu, materi yang disampaikan oleh narasumber merupakan nilai kebaruan (novelty) bagi pengabdian ini.

\section{METODE PELAKSANAAN}

Tim pengabdian bersama dengan Dr. Dwi Anggani LB, M.Pd sebagai narasumber utama, selama pelaksanaan program IbM melakukan pelatihan dengan memberdayakan guru SMPN 34 Semarang sehingga memiliki pengetahuan, pemahaman tentang menyusun soal berstandar UN. Narasumber utama dalam kegiatan pengabdian masyarakat kali ini merupakan narasumber dari Kemendikbud, oleh karenanya kegiatan ini menawarkan solusi melalui pelatihan dan pembimbingan dari tim pengabdian masyarakat Universitas PGRI Semarang dan narasumber utama yang bersedia mendampingi para guru tersebut melalui media digital supaya dapat tetap berkomunikasi sehingga para guru dapat dengan mandiri menyusun soal berstandar UN.

Pengabdian kepada masyarakat ini berbasis ilmu pengetahuan dan teknologi bagi masyarakat yang berjudul IbM Bagi guru SMPN 34 dalam menyusun soal berstandar UN untuk meningkatkan pemahaman dan pengetahuan para guru mengenai aturan dalam menyusun soal berstandar UN yang baik dan benar, kegiatan pengabdian kepada masyarakat tersebut dilakukan dengan kerjasama antara unsur pimpinan dan jajaran Universitas PGRI Semarang, Lembaga Penelitian dan Pengabdian Kepada Masyarakat, Dekan Fakultas Pendidikan Bahasa dan Seni, dan SMPN 34 Semarang.

\section{HASIL DAN PEMBAHASAN}

Program Pengabdian kepada Masyarakat ini berlangsung 2 hari, di dalam nya disajikan beberapa materi yang disampaikan oleh tim pengabdian kepada masyarakat. Kegiatan Pengabdian kepada Masyarakat bagi Guru SMPN 34 Semarang Dalam Menyusun Soal Berstandar UN ini memiliki nilai urgensi yang sangat tinggi karena berkaitan erat dengan kualitas lulusan di sekolah tersebut setiap tahunnya sedangkan seiring dengan itu kesulitan soal UN menjadi semakin meningkat. Apabila guru tidak memiliki kompetensi dalam menyusun soal berstandar UN maka kualitas pengajaran di kelas tidak akan meningkat dan peserta didik di sekolah tersebut akan mengalami kesulitan saat menghadapi UN karena terbiasa menghadapi soal ujian yang tingkat kesulitannya lebih rendah daripada UN. Oleh karena itu, peserta kegiatan pengabdian kepada masyarakat ini sangat antusias melaksanakan setiap materi yang diberikan.

Kegiatan Pengabdian ini berjalan dengan sangat baik. Materi pertama memberikan peserta pengetahuan mengenai bagaimana kaidah pengembangan soal terstandar. Materi kedua memberikan pengetahuan bagaimana bentuk pertanyaan berdasarkan Taxonomy Bloom. Materi ketiga memberikan mereka strategi bagaimana menyiapkan peserta didik untuk menghadapi UN. Dan Materi terakhir adalah tentang 
esensial UN 2016. Materi yang disampaikan dalam pelatihan ini merupakan materi paling up-date artinya materi yang sangat baru yang bersumber dari Kemendikbud. Kegiatan pengabdian ini berjalan sesuai dengan jadwal yang direncanakan, serta menghasilkan luaran sesuai dengan target tim pengabdi yaitu soal ujian berstandar UN yang disusun oleh guru dari mata pelajaran yang beragam.

Antusiasme peserta terlihat karena banyaknya pertanyaan yang muncul dari peserta yang artinya mereka benar-benar menyimak apa yang disampaikan oleh nara sumber utama dan tim pengabdian. Di samping itu, antusiasme membuat mereka mampu memahami dan melaksanakan kerja kelompok dengan baik di akhir sesi kegiatan ini dan mendengarkan pembahasan yang dilakukan oleh nara sumber utama. Tampaknya mereka sangat termotivasi untuk berlatih menyusun soal berstandar UN. Berikut adalah gambar kegiatan yang dilakukan oleh tim pengabdian masyarakat.

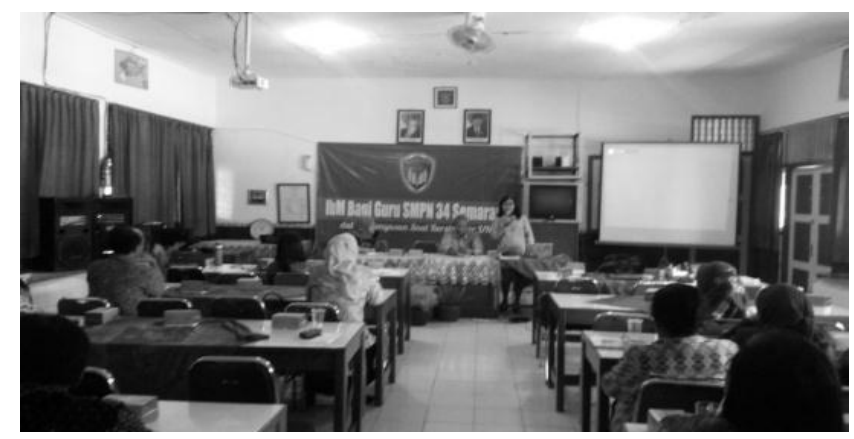

Gambar 1. Narasumber sedang Menjelaskan Materi

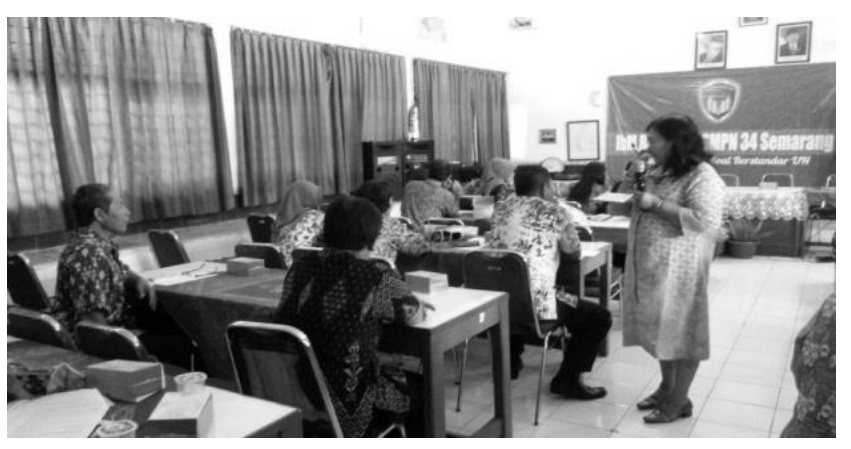

Gambar 2. Sesi Tanya Jawab

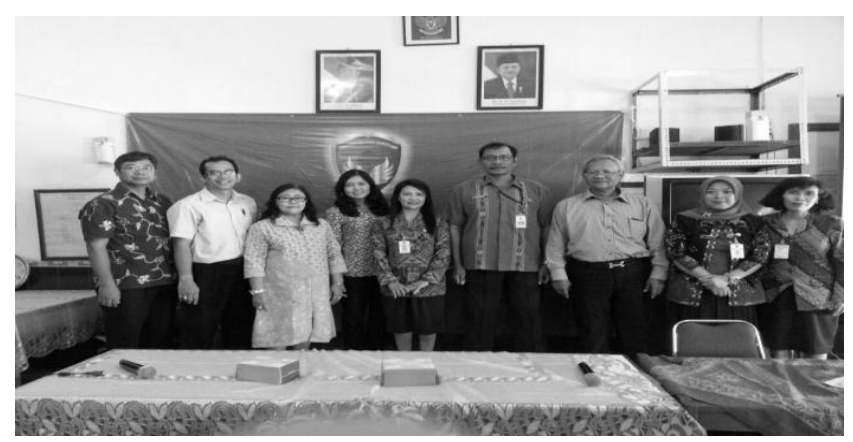

Gambar 3. Tim Pengabdian beserta Narasumber dan Pejabat SMP 34 Semarang 


\section{SIMPULAN DAN SARAN}

Dari hasil pelaksanaan kegiatan IbM bagi Guru SMPN 34 Semarang dalam menyusun soal berstandar UN, dapat diperoleh beberapa simpulan, sebagai berikut:

1. Kegiatan IbM bagi Guru SMPN 34 Semarang ini merupakan kegiatan yang sangat sesuai dengan kebutuhan peserta dalam hal ini adalah guru.

2. Kegiatan ini meliputi materi terkini bersumber dari Direktorat Jenderal Pendidikan Tinggi. Oleh karenanya respon peserta sangat positif, hal ini dibuktikan dengan tingginya antusiasme peserta dalam mengikuti kegiatan ini.

3. Setelah mengikuti kegiatan ini peserta mampu:

a. Mengetahui dan memahami materi tentang kaidah pengembangan soal terstandar UN.

b. Mengetahui dan memahami materi tentang bentuk-bentuk pertanyaan berdasarkan Taxonomy Bloom.

c. Mengetahui dan memahami materi tentang strategi bagaimana menyiapkan peserta didik menghadapi UN.

d. Mengetahui dan memahami materi tentang esensial UN 2016.

e. Menyusun soal berstandar UN.

f. Meningkatkan profesionalitas dan kompetensi guru SMPN 34 Semarang dalam menyusun soal.

Dalam kegiatan IbM ini, diperoleh beberapa saran yang bisa digunakan untuk melaksanakan kegiatan yang saling berkaitan, yaitu:

1. Kegiatan sejenis dapat melibatkan semua program studi yang terkait dengan UN.

2. Pelatihan menyusun soal berstandar UN pada MGMP tertentu.

3. Kegiatan yang meliputi monitoring dan evaluasi.

\section{DAFTAR RUJUKAN}

. (2007). Panduan Penulisan Soal Pilihan Ganda. Pusat Penilaian

Pendidikan Balitbang. Jakarta: Depdiknas

Arikunto, suharsimi. (2003). Penelitian Tindakan Kelas. Jakarta: Bumi Angkasa.

http://sukasains.com/tulisanku/dikala-guru-sulit-membuat-soal/ diakses 21 Januari 2016

http://malesbanget.com/2015/03/soal-ujian-ngaco-ini-adalah-bukti-pendidikan-

indonesia-buruk/ diakses 21 Januari 2016

http://ethsjhth.blogspot.co.id/cara membuat soal. Diakses 21 Januari 2016.

https://www.google.co.id/maps/place/SMP+Negeri+34/@-

$\underline{6.99813,110.4755517,16 \mathrm{z} / \text { data }=! 4 \mathrm{~m} 2 ! 3 \mathrm{~m} 1 ! 1 \mathrm{~s} 0 \times 2 \mathrm{e} 708 \mathrm{c} 52 \mathrm{f} 8 \mathrm{a} 4 \mathrm{bac} 5: 0 \times 1 \mathrm{~b} 7 \mathrm{e} 0 \mathrm{~d} 84}$

30393726?hl=en diakses pada 21 Januari 2016

Infoguru.blogspot.co.id diakses 20 Oktober 2015.

Pusat Pengembangan dan Pengembangan Bahasa. (1990). Kamus Besar Bahasa Indonesia. Jakarta. Balai Pustaka.

Safari. (2000). Kaidah Bahasa Indonesia dalam Penulisan Soal. Jakarta: PT Kartanegara.

Wiyono, Bambang B \& Sunarni. (2009). Evaluasi Program Pendidikan dan Pembelajaran. Malang: Fakultas Ilmu Pendidikan. 